\title{
Theorein and Praxis: Gender Political Troubles. An Interview With Martha Nussbaum
}

Diana Ibarra

Centro de Investigación Social Avanzada

diana.ibarra@cisav.org

$\mathrm{N}$ ussbaum's Capabilities Approach is one of the most meaningful perspectives towards the conflicts that come from social and cultural assumptions regarding gender. Martha Nussbaum, a prominent philosopher at the University of Chicago, proposes that philosophy should be deeply attached to the average people and their real-life problems. Since her early works: The Fragility of Goodness and The Therapy of Desire, her main concern has been to improve people's quality of life; from these works, any reader can have a better framework on what Nussbam recognizes as the main aspects for human development and how they can be obtained.

In her intellectual quest, she has become aware that in the historic distribution of wealth and other resources, women have not been considered in the same degree that men have, as they have left aside. She has came to the conclusion that: "many women all over the world find themselves treated unequally with respect to employment, bodily safety and integrity, basic nutrition and health care, education, and political voice." (Nussbaum, 1999: 5)

The following interview presents an adjustment on the concepts of theorein and praxis in Martha Nussbaum's political thought. This interview begins with a basic question, that is: which is the most suitable method to create philosophy and, then, it follows developing other questions related to which are the most relevant ways to solve the problems related to unequal distribution between private and public initiatives. 
Diana. - My interest in gender studies goes around the conception of a certain type of "essentialism". When you told me that you had changed your perspective over the years, I began to search for those changes in your works, and try to trace them. So, in relation with these changes, my first question is: have you changed your perspective of the phainomena for an intuitive method more related to supporting human capabilities?

Nussbaum. - No, I haven't changed my perspective of a method at all. My view of a method continues to be the same that Rawls' view of it, to what he proposes as his theory framework, i.e., we search for reflective equilibrium by considering our own moral judgments and then, holding them up against the main theories of the various traditions of philosophy that we know. So, my own perspective, what I think of it, is developed in my book Women and Human Development (WHD) (2000); where I stick to the capabilities approach, and the arguments developed against the utilitarian tradition; moreover, in Frontiers of Justice (2006), I moved on to the perspective of the social contract tradition, which I think, is a more complex point of view within the academic fields. So then, I just keep going on and reviewing other type of analysis over and over, until I decide which one represents a major opponent to my own view, and if I would want to treat it in the same way.

But, that is not where my perspective has changed. For me, the change has come in what I think, the results ought to be. That is, which would be an agreement for only political purposes, that is based on moral foundations (only for political principles), but that is not a comprehensive view of human development.

I am not asking the readers to have a more comprehensive view of my earlier works. I just want to make clear that I didn't address those issues, but it is not a contradiction. I should say that further on, I tried to make these aspects more clear. 
Diana. - Is there any anthropological base to support the capabilities approach? I understand that in a pragmatic way, every human has inside himself/herself the same possibilities to function; so everyone has something in common just for being a human being. However, in Frontiers of Justice and in Women and Human Development you said that your view is free from any metaphysical references. Is there any way to conciliate both of these arguments? Could this view be a hylemorphic way of approaching the human soul?

Nussbaum. - The first thing to say is that the capabilities view is a normative view. It is not a descriptive view at all. There are plenty of capacities that human beings have that are not considered part of the desirable capabilities list, because they are not evaluated as valuable, i.e.: the capacity for cruelty, the capacity to discriminate and so on. But you need to know what your possibilities are; the way that an anthropological view of human nature would evaluate them, it is to say, what materials you have to work with. That is the list of your possibilities. If you can't evaluate them, you just start in the middle of nowhere. Which ones of these do you think are particularly important? Which ones of this list are the ingredients for a life worthy of human dignity?

The other way that anthropology perspective can help you is giving you a better angle to see some problems that society has; for example, the fact that you want to treat everyone with respect, but then, you have to face a strong inclination towards hierarchy. As I was studying the history of social dissatisfaction, presented in my other book, I came to the conclusion that we should learn that society has some problems that we have to solve, for example hierarchy, in order to have the society we want.

Finally, I think that Anthropology can give you a sense of what could be wasted if you don't cultivate people in a certain way. For example, if we don't realize that people have artistic skills, we might just not think about them as important. We may think that we, as society, don't have to relate ourselves to imagination or to 
the artistic areas but, once we understand that imagination is such a powerful part of human nature, we should think that it would be a shame to waste this aspect.

To answer your initial question about hylemorphism, I think this theory is a good one considering that it makes sense if we relate it to a lot of our experiences as human beings; but let me propose another perspective: let's suppose that you are a cartesian dualist and you think that the soul is separable and immortal, and that it is not closely connected to a human being. I don't see any reason why a person can't accept this theory for political purposes. This theory is like any other perspective of the basic human requests. You may develop it in such a way that people with different religious or other conceptions of the soul and the body, could work together in accepting it.

Diana. - When I read in the The Fragility of Goodness (1986) about the aristotelian orexis, I was wondering if that perspective was, in a certain way, a beginning for the capabilities approach?

Nussbaum. - I think that perspective has a close connection because Aristotle is one of my main influences on the development of the capabilities approach. Also, this influence is presented again in the chapter II of Women and Human Development, where I discuss what's wrong with the complete rejection of desire from the political theory perspetive. Scanlon (2008), for example, treats desire as "utterly brutish", but the right understanding of desire suggests that it is much more selective. In this sense, I am using Aristotle again to criticize the Kantian rejection of desire, so I think there are Aristotelian ingredients that are still there.

Diana. —In your opinion, what is sex? Is it relevant in a biological way?

Nussbaum. -Once again, for political purposes, we want to present that issue in such a way that we can get consensus among people who have very different views. We have reasons to think 
that the differences between men and women are biologically relevant to reproduction, consequently, a "good "society has to take those reasons into account, since a "good" society has to consider some aspects such as the treatment of infertility, the problems of unwanted pregnancy, etc. For example, if we consider an equal treatment of all citizens, you have to think about the problems that pregnancy imposes on women in their workplaces. In the United States, we used to have some laws that said that women couldn't get any kind of insurance coverage for pregnancy. Then, the Supreme Court abrogated those laws, for considering them as a form of sex discrimination. The insurance companies replied that it wasn't any sex discrimination, because pregnant men weren't getting those benefits either. The Court said that it was unrealistic, but there was a difference: women can be pregnant and men cannot. So, the Court established that if you were denying those benefits to women, it was a form of sex discrimination.

To not recognize biological differences between men and women can give a blind, one side perspective, connected with discrimination against women. On the other hand, it is also very important that a society shouldn't be built around stereotypes based on these biological differences. Let me give you another example, there was a famous case about the Virginia Military Institute, a military college that prepared people for the military service but that was open only to men. Women challenged the institution. The State of Virginia said that they had a program for women, because they don't learn the same things, because women are different, and because they don't need to learn the same things that men. So the Supreme Court replied that for many years women had been held back by those stereotypes about what can they do and what can't they do, and their final response was to insist on full equality between men and women. As a conclusion, I should say that there is a very delicate balance between how to recognize the relevance of a biological difference and not taking it too far, when we build serious distinctions. 
Diana. - Now, coming form this perspective, I have a question related to what you said before. From an anthropological perspective, I want to accept those differences, but I don't want to say that this is how women should be treated.

Nussbaum. - I think you should stick to what is strictly physiological, to what I related merely to the body. Let me make it clear, the fact is that it is only a woman, and not a man, who can get pregnant from unwanted sex, that fact makes a big difference. This is connected to why the woman is the only one who should have the right of decide about abortion, simply because it is not a man's issue, and because she is the one who is burdened by the consequences. So, you stick only to the biological aspects and don't allow others to move over into the stereotypes of "women are not good at math" and "women can't be lawyers". There have been so many centuries of discriminatory practices that are built on these stereotypes.

Diana. - My main concern is about the modification of structures that will enable women to have a better quality of life. I am absolutely convinced that the capabilities approach is a suitable theory to analyze how to solve the problems related to these structures, and what helps you to think about the main needs of human beings' life. So, in your opinion, how can we modify the psychic male domination that is present in our days and that makes equity a difficult goal?

Nussbaum. - You should have a lot of different strategies and combine them. One obvious thing is to work on education and on the schools, to make sure that these institutions give the same opportunities to women, and that they do not engage in male/ female stereotypes. We have done a lot of studies of how women are subtly put aside from the Math and Science fields. Now, teachers are much more aware of how they behave towards these areas. There are affirmative programs that focus on getting girls more involved in Math and Science. But this is just one area, focused only 
on schools. Obviously, that is not the whole picture. You also have to focus on family too, but there is a limit to what the government can do about it, that is where you run against some obstacles. So, what else can government do? Government can work, from the other end, trying to remove impediments to women's full participation in the working places, for example, by providing much more family and medical leave, support for child and elderly care. All those things make a tremendous difference because women, much more than men, are doing both child and elderly care. Our country has done very little with those issues but there are other countries where you really can get a very generous leave, not only for childcare, but also if you are caring for another relative.

Our university has been working on a new policy that will make these new and better work conditions possible. Of course, some of these benefits can be given to men under certain circumstances, but they have to prove that they are the main care providers. We have been having a lot of discussions among the members of the faculty because, now, we have a lot of young people, both men and women who have babies; but women are often more involved, dealing with the early years of their children and, because of this fact, they are much more constrained, since they are breastfeeding. The question among the faculty has been this: can we make more flexible teaching schedules? Or can we change the teaching role? Maybe, one person can teach three courses one semester, no courses on the following semester; or maybe, one can teach two days a week rather than three. We have been experimenting with all these aspects to establish the workplace as a very important part of the solution. Nowadays, with all the technology advantages that we have available, it is very easy to have people working from home during a part of the workday; but employers are not taking advantage of those aspects as much as they should. Though, I think that a suitable schedule and taking advantage from technology can make a difference for women in order to balance their role as workers as well as mothers. 
Finally, I want to conclude, with the old story of role models and having women in authority positions that is quite important, that is one of the justifications for affirmative action. When people see women in an authority position, they come to perceive them differently, and this change can often happen very quickly. If you look at any religion in the United States, there were no female ministers in the Protestant churches fifty years ago; there were no female Rabbis in the Jewish tradition either. Now more than $50 \%$ of the rabbis, from the Reformed Judaism -that is my own religious tradition- are women. In the Anglican Church, where I grew up, the presiding bishop is now a woman, and there is a very large proportion of Anglican ministers who are women. This is an extremely rapid change.

It is quite counterproductive of the Roman Catholic Church, to not allow women to become priests because we have seen so many women who would like that kind of ministry. This institution has been having terrible problems recruiting priests in the United States so, why don't they see women role within the church as a part of what they should be doing?

I think the role model changes people's perception quickly. I remember that in our congregation we hired a female cantor that did most of the singing during the religious services; when she sang for the first time, people said that how could they pray with a woman who was singing. About two months later, the congregation got used to her singing. So, as we have seen, the change in people's perception within religious traditions is very important. I just hope that it is happening in politics too.

Diana. - Some of the feminist members of academic life in Mexico perceive maternity and nurturing as bad consequences of being a woman, and also as problems women should get rid of, but I do not agree with this perspective.

Nussbaum. - I think it is important to get rid of the stereotypes that only women are nurturing and providing care, because after 
all, that is the main issue that holds women back. Men assume that women's nature is to be nurturing, so they use that as an excuse. Of course, they do not want to do any work. In the same way, men assume that taking care of elderly people is a part of women's nature, and that they will do that out of love, so men don't have to worry about it.

We should understand that both, men and women, can be nurturing; but, from a strictly biological point of view, pregnancy and breastfeeding impose particular demands on women, and these demands should be supported through medical insurance policies and medical leave. We should fight for a world in which it is right to recognize these aspects, in which the workplaces are arranged in order to meet women's needs.

About thirty years ago, in the law school of my university, people were afraid even to put a picture of their children on their desk because that would be considered as if people were admitting that they were not fully attached to their work. This happened not only to women; men were afraid, too.

Nowadays, it is not good if women are the only ones who want to take care of their children and ask for help to do that. It is important that young men can also say that. Fortunately, that is happening now and more frequently. Since we have career couples, men also have to be involved in their families' care because their wives are working too.

Diana. - When you speak about the "threshold of legitimacy" (2006: 259) and the adaptive preferences of women (2000: 111-161), how can we be sure that our political institutions, "when we judge an old tradition", are not also influenced by cultural patterns?

Nussbaum. - You can never really be sure. Of course you never judge from nowhere, but the only way to do it is to learn more History and see how cultures shape people's preferences and 
compare them more. Look around the world and see how different ways of doing things work in different places. Also, you should be constantly critical and self-critical.

\begin{abstract}
Diana. - Sometimes we try to create measures to solve social injustice but, ironically, we get unexpected consequences. For example, in Mexico City, there is a program for single mothers. The government gives them financial support. A big problem is that a lot of men have several women, so they put the responsibility of their children in the State and in the mothers' hands. That happens especially in the low economic classes. There we can find a lot of women who live as single mothers without any support from the fathers of their children, so they stay with a minimum financial aid and with the responsibility of raising their children by themselves. What is your opinion about this?
\end{abstract}

Nussbaum. - You don't want to make it a desirable goal because, then, you will have people trying to get money that way. In the States, we have something of that problem too but from another perspective: a lot of young men in our city communities have women who get prestige from having children at a young age. This is more a cultural issue than a financial one. People do not really get any financial aid, but the incentive comes because they do not have any other source of prestige.

You have to encourage everyone, both males and females, to finish high school, and continuing to have some professional training or school. This is my main focus: education. If you make certain choices, that is fine, but the important thing is that you are educated in such a way that you will have employment options, and that you can really support yourself. So, if you need to be financially supported by some program, even if it is for a short time, this fact wouldn't turn into a form of lifelong dependency.

Diana. - I agree with you that the concept of a human being shouldn't be defined merely because of its rationality. The body 
is a reality that we assume every day of our life. However, average people are more concerned with their looks and appearance and validate other people regarding their body, not their intelligence. How can we become honestly and truthfully aware of our body's dignity without becoming hedonist?

Nussbaum. - The eighteenth century perspective moved human beings to say that they were all just rational beings. People don't always understand that it was not about being cold or heartless. It was about trying to get people to pay attention to something that was deeper and that went beyond the superficial aspects of wealth and class, and who your parents were. So, you rightly ask how we can have something broader than that. Well, one way we can get this perspective, without being hedonist, is by recognizing that emotional fulfillment is very important; friendship and love, too; these are things that are deep and not merely superficial, and yet, we might think that they are not included in the rationalist account. But I also think that you don't want to be too anti-hedonist. That is to say, to avoid the list of things people like and need in life, for example "to play", that is in my list too.

Diana. - It surprises me that you include "to play" in the list of people's needs, because, when I think about the needs of life, then "play" is not the first thing I think of, but it is very true.

Nussbaum. - Play is the way that people usually express as leisure time; but what is leisure time good for? It is for pointless, purposeless forms of self-expression. However, these aspects are so important in life. I have developed in some of books like Upheavals of Thought (2003) a theory in which Donald Winnicott's perspective on "play" takes an important part.

My theoretical approach to this is that it is through imaginative play that we learn the difference between the self and others. We learn what it is to be attentive to the feelings of another being. This is why the arts are so important, and that is a long story. A shorter 
story is that people want a life that is expressive, that is playful, and that involves joy and fun.

We were talking about these aspects the other day in a round table of the law school of my university. We were discussing, on the one hand, that you don't want people to be so conscious of fashion, so they will put down other children just because they don't have the right clothing. But, on the other hand, you don't want a society, like the one in the Maoist China, in which they were so strongly against fashion that they denied self-expression and everyone was wearing the same clothes.

As a contrast, in India, even the poorest people love to wear bright colors. They dress in ways that are personally expressive, even though they don't have much money. I think we ought to go towards encouraging self expression.

Actually, I like the fact that Michelle Obama wears clothes that are designed by young designers from different countries, because in this way, she shows the world that she can have fun and at the same time be serious.

Diana. -You speak about redesigning public spaces to allow a person in a wheelchair to be able to move. Do you think this modification, and the creation of possibilities for people with disabilities, should be made only by the State or that private initiative should be involved? What is the role of the private sector in this minority's problem?

Nussbaum. - There are lots of different views on this issue, but the basic anti-discrimination law also applies to most private institutions. It is a complicated legal aspect in the United States, because there is a concept called "public accommodation." We consider a public accommodation as a place that is large enough to be opened to a wide group of people; these places are bound by the law of non-discrimination. If you rent an apartment, if you 
own an apartment building, or if you are in a one-family house, you are not bound by this anti-discrimination law. But once you have an apartment house that is of a certain size different from the law standards, or if you are going to advertise it to the public, even though this apartment is located in a private building, you cannot discriminate on a race or sexual orientation perspective; the same perspective should be true according to the law of disability.

Chicago University is a private university, but we still have to have disability access, and we do; but there are a lot of different opinions about how many access should the new constructions have or about re-building older buildings in order to have them. The basic idea is that once you are offering services that go beyond the immediate family you cannot discriminate, whether these services are private or public.

\section{Diana. - The problem begins when we leave this responsibility only to the State, especially in countries such as Mexico, where a tradition of corrupt government institutions should be considered. How can we obtain these changes regarding capabilities? I know you mention this in Frontiers of Justice, but can you explain yourself a little more?}

Nussbaum. - I think that what you described is a very non-ideal situation. The reason that government should take responsibility for the basic and essential capabilities is because, first of all, government depends on people; people can choose it and can change it. A second reason is that, since government implies a certain norm of impartiality, it is not going to be for women or for men; government is for everyone, and it should be treating all people in the same way. Private organizations don't have to be impartial. I mean there are Catholic and Protestant organizations that follow their own principles, and so, it is perfectly legitimate for them to think about the interests of their own members.

Of course, governments can delegate part of their function to private agencies. For example, one of our highways in Chicago was 
contracted out to a private developer. They were going to maintain the highway and they were going to get fees from the highway. But, if they made mistakes, the government had to be responsible for those because they made that arrangement. Actually, the government tried to make another arrangement where some private company would be responsible for parking meters, and it just turned out that they did a very bad job and everyone was upset about this so, immediately, the mayor's office got the complaints, and that was quite right. Since it was his bad decision, he will have to fix it.

Whenever the private initiative does something that is not under the control of the government, it could be a nice supplement, but it should not be part of fulfilling central human needs. But, on the other hand, when you have a government failure like corruption, what can happen at the end is that private initiative takes in its hands some of the government tasks. For example, in India, a lot of the education is provided privately because the government schools are not doing their job. These conditions are non-ideal, because the minute the private initiative is doing the government tasks, we can have all kinds of preferences and unfairness, since the Hindu right wing would provide their own school systems. In this sense, someone can lose the perspective that we are all citizens and that we deserve a common treatment on the basis of equality.

Diana. - Thank you Professor Nussbaum for your time and inspiring words. From this interview I come to the conclusion that every political theory should take into account the unequal recognition of women as members of the State. That is why we need to come back to committed thinkers that acknowledge human in order to see what are their answers and how they comprehend the world. Politics should be made by people who are seeking the truth, even though they know it is not an easy task. The fruits we will harvest will provide better possibilities for our future. 


\section{BIBLIOGRAPHY}

Nussbaum, Martha. 1986. The Fragility of Goodness: Luck and Ethics in Greek Tragedy and Philosophy, Cambrdige, Cambridge University Press.

Nussbaum, Martha. 1999. Sex and Social Justice, New York, Oxford University Press.

Nussbaum, Martha. 2000. Women and Human Development, Cambridge, Cambridge University Press.

Nussbaum, Martha. 2003. Upheavals of Thought. The Intelligence of Emotions, Cambridge, Cambridge University Press.

Nussbaum, Martha. 2006. Frontiers of Justice: Disability, Nationality, Species Membership, Cambridge, The Belknap Press of Harvard University Press.

Scanlon, T.M. 2008. Moral Dimensions: Permissibility, Meaning, Blame, Cambridge, Harvard University Press. 